\title{
Cinsel Saldırı Suçuna Sürüklenen Çocuğun Cinsel İstismarı: Olgu Sunumu
}

\section{Child Sexual Abuse Whom Trailing into the Crime of Sexual Assault: A Case Report}

\author{
Tülay Elbek ${ }^{l}$ Özlem Erel ${ }^{2}$, Musa Dirlik², Selim Özkök ${ }^{3}$,Hatice Aksu', Füsun Çallak Kallem', \\ Bedir Korkmaz', Ufuk Katkıcl \\ ${ }^{I}$ Arş.Gör.Dr. Adnan Menderes Üniversitesi Tıp Fakültesi Adli Tıp Anabilim Dalı, Aydın \\ ${ }^{2}$ Doç.Dr. Adnan Menderes Üniversitesi Tıp Fakültesi Adli Tıp Anabilim Dalı, Aydın \\ ${ }^{3}$ Prof.Dr. Adnan Menderes Üniversitesi Tıp Fakültesi Adli Tıp Anabilim Dalı, Aydın \\ ${ }^{4}$ Yrd.Doç.Dr. Adnan Menderes Üniversitesi Tıp Fakültesi Çocuk Psikiyatrisi Anabilim Dalı, Aydın
}

\section{Özet}

Kimi zaman bir ceza yöntemi olarak kullanılan cinsel istismar yönünden cezaevleri özellikle çocuklar açısından yüksek riskli alanlardır. Bu makalede cinsel istismar suçunu işleyen ve bu suç nedeniyle cezaevindeyken cinsel istismara uğrayan bir olguyu sunarak çocuk haklarına dikkat çekmek istedik.

İki kişi tarafından cinsel istismara uğradığı iddia edilen 10 yaşında erkek çocuğun muayenesinde; anüste enfekte alanla fibröz bantlar, anüse doğru uzanan ekimozun olduğu, anal pililerin simetrisinin bozulduğu, anal tonusun hafif azalmış olduğu ve anüsün ovalleşmiş görünümde olduğu saptandı.

Cinsel istismar suçu işlediği iddia edilen 14 yaşında erkek tutuklandı. Tutuklandıktan 9 gün sonra kliniğimize başvurdu. Vücudunda ekimoz ve abrazyonlar saptandı. Aynı koğuştaki diğer çocuklar tarafından dövüldüğünü iddia etti. İki ay sonra aynı çocuk, tuvalette darp edildiği ve anüsten kalem sokulduğunu iddia ederek kliniğimizde muayene edildi. Muayenede darp ve fiili livata bulgularına rastlanmadı. Psikiyatrik değerlendirmesinde travma sonrası stres bozukluğu tanis1 kondu.

Birleşmiş Milletlerin Çocuk Hakları Sözleşmesi'ne göre devletin, çocuk haklarını koruması zorunludur. Cezaevlerinde de çocuk hakları korunmalıdır.

Fail ve mağdur olan olgumuz, cezaevinin suçun önlenmesinde etkisiz kalması nedeniyle, cinsel istismar, suç ve cezaevi ortamından yeterli derecede korunamamıştır.

Anahtar Kelimeler: Suç; Çocuk hakları; Cinsel istismar.

\section{Giriş}

Dünya Sağlık Örgütü, bir çocuğun sağlı̆̆ını ve gelişimini olumsuz yönde etkileyen davranışları çocuk istismarı olarak tanımlamakta ve istismarı fiziksel, cinsel ve

Sorumlu Yazar: Dr. Tülay Elbek

Adnan Menderes Üniversitesi Tip Fakültesi

Adli Tip Anabilim Dall, Aydin

E-posta: tulayelbek@yahoo.com

Geliş: 13.04.2015 Düzeltme: 22.05.2015 Kabul: 26.06.2015

\section{Abstract}

Prisons are especially high-risk areas for children because sexual abuse is used for punishment in prisons. We aimed to draw attention to children's rights by presenting a case of sexual abuse offender who became a sexual abuse victim while in prison because of this crime.

In the examination of a 10 -year-old boy who was allegedly sexually abused by two people, there were infected fibrous bands, ecchymosis extending to the anus, anal deterioration of symmetry of pleats, mildly decreased anal tone and oval view of anus.

A 14-year-old boy was allegedly committed to sexual abuse crime and was arrested. He admitted to our hospital 9 days after the arrest. There were ecchymosis and abbresions on his body. He claimed that he was beaten by the prisoners in the same ward. Two months later, the same boy admitted to our department and claimed that he was beaten in the toilet and underwent anal rape with a pen. There was no clue of beat or rape in the examination. In the psychiatric assessment, he was diagnosed as post traumatic stress disorder.

According to the The United Nations Convention on the Rights of the Child, rights of the children are protected by the state. Even in prisons, rights of the children should be protected.

In our case, the perpetrator and the victim could not be adequately protected children from sexual abuse, crime and prison environment that is ineffective in the prevention of crime suggests that contribute to prison again.

Keywords: Crime; Children's rights; Sexual abuse.

duygusal olarak sınıflandırmaktadır (1). Dünya genelindeki epidemiyolojik çalışmalar kız çocukların \%20, erkek çocukların \%5-10'nunun cinsel istismara uğradığına işaret etmektedir (2). Türkiye'de ise toplumun tümünü örnekleyecek veriler olmamakla birlikte Türkiye Büyük Millet Meclisi'nin Çocuk ve Gençlik Kapalı Ceza İnfaz Kurumları ve Eğitimevleri İnceleme Raporu'nda, inceleme yapılan kimi kurumlarda cinsel istismar suçundan do- 
layı tutuklu ya da hükümlü çocuk oranının \%56'ya ulaştığı ve kurumların fizik yapılarının yetersizliği nedeniyle çocukların koğuş ortamlarında cinsel istismara uğradıkları belirtilmektedir (3). Ancak bu noktada yaşanan sorun sadece kurumların fiziki yetersizliği ile açıklanamaz. Aksine cinsel istismarın hedefi ve cezaevi kültürü ile ilișkisi de göz önüne alınmalıdır. Gerçekten de cinsel saldırıda aslında amaç arzunun tatmin edilmesi değil, aksine mağdur üzerinden öfkenin boşaltılması ve güç gösterisinin sergilenmesidir (4). İşte biz de bu makalede, cinsel istismar nedeniyle tutuklanan bir çocuğun cezaevinde cinsel istismara uğramasından hareketle sorunun çok tartışılmayan bu boyutuna dikkat çekmeyi amaçliyoruz.

\section{Olgu}

10 yaşında erkek hasta iki kişi tarafından cinsel istismara uğradığı iddiasıyla kliniğimize başvurdu. Yapılan görüşmede hastanın ilkokul dördüncü sınıfa devam ettiği, babasının ilkokul mezunu inşaat işçisi ve annesinin okuryazar olmayan ev kadını olduğu, kendisinden büyük bir kardeşinin bulunduğu, ailenin aynı evde yaşadığı öğrenildi. Fizik muayenede; anüste 10-11 hizasında enfekte alan ve fibröz bantlar; saat 1 hizasında pililere paralel seyirli 0.3 santimetrelik anüs iç kısmına doğru uzanan kırmızı renkli, iyileşmekte olan ekimoz; anüs iç kısmında saat 1 ve 2 hizasında anal pililere paralel seyirli 0.2 ve 0.3 santimetrelik kırmızı renkli ekimoz olduğu; ayrıca anal pililerin simetrisinin bozulduğu, anal tonusun hafif azalmış olduğu ve anüsün ovalleşmiş görünümde olduğu saptandı.

Cinsel istismar suçunu işlediği iddia edilen 14 yaşında erkek hasta ile yapılan görüşmede; halen ilköğretim sekizinci sınıfa devam ettiği, kendisinden küçük bir kardeşi daha olduğu, okuma yazmayı ikinci sınıfta öğrendiği, babasının lise mezunu bir kahveci annesinin ise lise mezunu ev kadını olduğu öğrenildi. Cinsel istismar suçu nedeniyle işlediği iddia olunan suçun hukuki anlam ve sonuçlarını algılama ve davranışlarını yönlendirme yeteneğini tespit etmek açısından Çocuk Psikiyatrisi konsültasyonu istendi. Ancak Cumhuriyet Savcılığı zaman kısıtllılı̆̆ını gerekçe göstererek hastayı Adli Tıp Şube Müdürlüğü’ne sevk etti ve söz konusu şube müdürlüğünün görüşü üzerine olgu tutuklandi.

Cinsel istismar suçunu işlediği iddia edilen ikinci erkek hasta ile yapılan görüşmede olgunun 15 yaşında olduğu ve halen lise birinci sınıfa devam ettiği öğrenildi. Babası hamal, annesi ise ev kadını olan hastanın kendisinden büyük bir kardeşi mevcuttu. Tarafımızca yapılan değerlendirilmede cinsel istismar suçu nedeniyle işlediği iddia olunan suçun hukuki anlam ve sonuçlarını algılama ve davranışlarını yönlendirme yeteneğinin geliştiği saptandi.
Adli Tıp Şube Müdürlüğü’nün görüşü doğrultusunda tutuklanan 14 yaşındaki erkek hasta 9 gün sonra koğuş arkadaşları tarafından darp edildiği iddiasıyla kliniğimize başvurdu. Hasta ile yapılan görüşmede; koğuş arkadaşlarının yumruk, tokat ve sopa ile darp edildiğini ifade etti. Olgunun fizik muayenesinde; sağ ve sol alt göz kapağında, sol göz lateralinde, sol zigomatik kemik üzerinde, alında, her iki kulak aurikulasında, sağ parietal bölgede, sağ ve sol omuzda, sağ üst kolda, sağ ve sol dirsekte, sağ ön kol lateral yüzde, sağ el bileğinde, sirtta, sol tibia ön yüzünde ve sol dizde yaygın ekimoz saptandı. Benzer biçimde vücudun çeşitli bölgelerinde abrazyonlar tespit edildi.

Aynı hasta darp edildiği zamandan yaklaşık iki ay sonra koğuş arkadaşları tarafından darp edildiği ve fiili livatada bulunulduğu iddiasıyla kliniğimize başvurdu. Yapılan görüşmede; koğuştaki arkadaşlarının kendisini tuvalete götürerek dövdüklerini ve makatından kalem soktukları öğrenildi. Anca hastanın fizik muayenesinde darp, cebir ve fili livata bulgularına rastlanmadı. Fakat kalem kullanılarak yapılan fiili livatalarda organik bulgu saptanamayabileceği bilindiği için Çocuk Psikiyatrisinden konsültasyon istendi. İlgili bölümün değerlendirmesinde; hastanın afektinin anksiyöz olduğu, hafif düzeyde zekâ geriliği tespit edildiği, klinik olarak sınır-donuk düzeyde zihinsel işlevselliğinin bulunduğu, darp ve fiili livata nedeniyle travma sonrası stres bozukluğu mevcut olduğu, yaşadığ 1 iddia olunan cinsel istismar, cebir tehdit veya hile kullanılarak hürriyetinden yoksun kılma olay1 nedeniyle halen ruh sağlığının bozulduğu saptandı.

\section{Tartışma ve Sonuç}

Türkiye tarafindan 15 Ağustos 2010 tarihinde kabul edilen Birleşmiş Milletler "Kişisel ve Siyasi Haklar Uluslararası Sözleşmesi”nin 10. maddesi özgürlüğünden yoksun bırakılmış herkesin, insani muamele ve insanın doğuştan sahip olduğu insanlık onuruna saygı görme hakkına sahip olduğunu hükme bağlamaktadır (5). Ancak olgumuz aslında bu hükmün pek çok kez ihlal edildiğine işaret etmektedir.

Bilindiği üzere devletin tutuklu ya da hükümlü olarak özgürlükten yoksun bıraktı̆̆ kişilere karşı bakım, gözetim ve koruma sorumluluğu vardır. Öte yandan Çocuk Haklarına Dair Sözleşme kapsamında devletlerin çocuğun esenliği için gerekli bakım ve korumayı sağlamayı üstleneceği belirtilmiş ve "çocukların bak1mı veya korunmasından sorumlu kurumların, hizmet ve faaliyetlerin özellikle güvenlik, sağlık, personel sayısı ve uygunluğu ve yönetimin yeterli” olması gerektiğine dikkat çekilmiştir (6). Öte yandan Türkiye'de 5395 sayılı Çocuk Koruma Konunu suça sürüklenen çocukların 
korunmasına, haklarının ve esenliklerinin güvence altına alınmasına ilişkin usûl ve esasları düzenlemektedir. Her ne kadar bu hükümler çerçevesinde soruşturma ve "kovuşturma sürecinde çocuğun durumuna uygun özel ihtimam gösterilmesi" belirtilmişse de, olgumuz özelinde Cumhuriyet Savcılığı, zaman kısıtlığı gerekçesiyle talep ettiğimiz Çocuk Psikiyatrisi konsültasyonu göz ardı edilmiş ve ilgili Kanun'da "en son çare olarak başvurulması" olarak tanımlanmış hapis cezası hızla uygulamaya konulmuştur. Bu durum Türkiye'de kanunlarda tanımlanmış hükümlerin tam anlamıyla yaşama geçirilemediğine işaret etmektedir.

Bilindiği üzere mahkûmlar arası ilişkileri belirleyen cezaevi alt kültürüdür (7). Öte yandan Foucault, hapishaneyi bir "islah etme" mekânı olarak tanımlamakta ve adaletin, "yüksek" bir amaç uğruna, hekimler, psikiyatrlar, psikologlar ve eğitmenler gibi "teknisyenler ordusu" eşliğinde ve belirli kurallar uyarınca mahkûmların bedenlerine müdahale ettiğini öne sürmektedir. Bu bağlamda tutuklamanın ana amacı bireyin tutumunu dönüştürmek ve onu "1slah" etmektir. Ancak Foucault'ya göre aslında hapishaneler hiyerarşik bir düzen ve dayanışma ortamı yaratarak "her şeye hazır bir suçlular ortamını mümkün kılmakta"dır (8). Öte yandan bir kişinin hapishaneye girmesinin onun "lekeli" olarak tanımlanmasına ve hapishaneden çıksa dahi bu damgalanma nedeniyle suç işlemeye eğilimli birisi olarak kalmasına yol açtığı gösterilmiştir (9). Bununla birlikte cinsellik temelli kurulan "namus" olgusu kolaylıkla şahsileştirilebilmekte ve hapishane gibi hiyerarşik mekânlarda hem yeniden üretilmekte hem de mahkûmlar arasında bir "takdir" öğesi olarak tanımlanmaktadır (10). Bizim olgu özelinde de cinsel istismar suçuna sürüklenmiş bir çocuğun yaptığ 1 eylemin cezaevi alt kültüründe pek muhtemelen bir "namus" saldırısı olarak algılandığını ve "namus"a uzanan eylemin hapishane ortamında aynı biçimde karşılıkla yanıtlandığını düşündürtmektedir. Öte yandan cezaevinde cinsel istismara uğraması hapishane ortamının suça sürüklenmiş bu çocuğun haklarını koruyamadığını da işaret etmektedir.

Son olarak; erkek çocuklarda genellikle iz bırakmadığı için cinsel istismarın tanısı oldukça zordur (11). $\mathrm{Bu}$ nedenle hekim-hasta güven ilişkisinin kurulduğu bir ortamda dikkatli biçimde öykü alınması ve mağdurun açık ve kesin ifadesine ulaşılması temel hedef olmalıdır. Ayrıca ruhsal değişimlerin saptanması ve gerekli incelemelerin yapılması da tanıya katkı sunacaktır. $\mathrm{Bu}$ bağlamda Gaziantep’te yapılan bir araştırmada kız çocukların \%33'ünde, erkek çocukların ise \%50'sinde cinsel istismara yönelik bedensel bir bulgu saptanmamış ve tanı ruhsal muayene değerlendirilmesi ile konulabilmiştir (12). Bizim cinsel istismara uğrayan hastamızın da ifadesinde açık ve kesin livata ifadeleri alınmasına rağmen bedensel bir muayene bulgusu saptanmadı, ancak ruhsal durum muayenesi sonrasında cinsel istismara uğradığ 1 tespit edildi.

Özetle; olgumuz, var olan mevzuata rağmen fail ve mağdur olarak çocukların cinsel istismardan yeterince korunamadığına, cezaevlerinin suçu önlemede etkisiz kaldığına ve daha önemlisi cezaevi ortamının suçu yeniden üreten bir zemin olduğuna işaret etmektedir.

\section{Kaynaklar}

1. Krug EG, Dahlberg LL, Mercy JA, Zwi AB, Lozano R. World report on violence and health [Internet]. Geneva, World Health Organization; 2002 [cited 2014 Jul 10]. Available from: http://www.who.int/violence_injury_ prevention/violence/world_report/en/full_en.pdf?ua $=1$

2. WHO. Promoting research to prevent $\overline{c h}$ ild maltreatment [Internet]. XIXth ISPCAN International Congress on Child Abuse and Neglect; 2012 [cited 2014 Jul 10]. Available from: http://www.who.int/violence_injury_prevention/ violence/child/ispscan_report_june2013.pdf

3. Türkiye Büyük Millet Meclisi İnsan Haklarını İnceleme Komisyonu. Çocuk ve Gençlik Kapalı Ceza İnfaz Kurumları ve Eğitimevleri İnceleme Raporu [Internet]. [cited 2014 Jul 10]. Available from: http://www.tbmm.gov.tr/komisyon/ insanhaklari/belge/cocuk_ve_genclik.pdf

4. Gölge ZB. Cinsel saldırı olgularının suç motivasyonuna göre sınıflandırılması. Adli Tıp Dergisi. 2007;21(2):11-19

5. Türkiye Büyük Millet Meclisi İnsan Haklarını İnceleme Komisyonu. Kişisel ve Siyasi Haklar Uluslararası Sözleşmesi [Internet]. [cited 2014 Jul 10]. Available from: http://www. tbmm.gov.tr/komisyon/insanhaklari/pdf01/53-73.pdf

6. UNICEF Türkiye. Çocuk Haklarına Dair Sözleşme [Internet]. [cited 2014 Jul 10]. Available from: http://www. unicef.org/turkey/crc/_cr23c.html

7. Kızmaz Z. Cezaevinin ve hapsetmenin suçu engellemedeki etkisi. Dumlupınar Üniversitesi Sosyal Bilimler Dergisi, 2007; 17:44-69.

8. Foucault M (Çev: Kılıçbay MA). Hapishanenin Doğuşu. 3. Bask1. Ankara: İmge Kitabevi; 2006.

9. 9Foucault M (Çev: Ergüden I). İktidarın Gözü. Birinci Basım. İstanbul: Ayrıntı Yayınları; 2003.

10. Öztürk M, Demirdağ MA. Namusun gölgesinde yatmak: Mardin Cezaevi mahkûmlarının namus algısı üzerine bir araştırma. Suç Önleme Sempozyumu. 7-8 Ekim 2011, Bursa.

11. Tıraşçı Y, Gören S. Çocuk istismarı ve ihmali. Dicle Tıp Dergisi, 2007;34:70-74.

12. Isır AB, Büyükçelik A, Özdil S, Coşkun AG. Gaziantep Üniversitesi Tıp Fakültesi Adli TıpAnabilim Dalına Yansıyan Cinsel İstismar Olgularının ve Bu Olgular İçinde Çocuk İstismarı ve Mental Retardasyonun Değerlendirilmesi. Bull Leg Med. 2009;14(1):5-11. doi: 10.17986/blm.2009141683 